\title{
Pelatihan Pengembangan Perangkat Pembelajaran Abad 21 Dengan Model Pembelajaran Project Based Learning Berbasis STEM Bagi Guru IPA
}

\author{
Ryan Ardiansyah $^{1}$, Dea Diella ${ }^{2}$, dan Herni Yuniarti Suhendi ${ }^{3}$ \\ ${ }^{1,2}$ Jurusan Pendidikan Biologi, Fakultas Keguruan dan Ilmu Pendidikan, Universitas Siliwangi \\ ${ }^{3}$ Pendidikan Fisika, Fakultas Tarbiyah dan Keguruan, UIN Sunan Gunung Djati Bandung \\ 1yanardiansyah@unsil.ac.id \\ 2deadiella@unsil.ac.id \\ 33herni.suhendi@uinsgd.ac.id
}

\begin{abstract}
ABSTRAK
Pelatihan ini bertujuan untuk melatih guru IPA yang tergabung sebagai anggota MGMP IPA wilayah Barat Kabupaten Tasikmalaya tentang cara pembuatan perangkat pembelajaran (RPP dan LKPD) dengan menggunakan model Project Based Learning (PjBL) berbasis STEM. Kendala yang biasa dihadapi oleh guru IPA dalam implementasi pembelajaran adalah selalu terbiasa menggunakan format lama dan model pembelajaran discovery learning yang memang dianggap selalu relevan dengan seluruh konsep. Padahal beberapa kompetensi dasar menuntut untuk diterapkannya model pembelajaran seperti PjBL berbasis STEM untuk diimplementasikan di dalam kelas sehingga guru IPA perlu melakukan kegiatan penyegaran dengan mengikuti kegiatan pelatihan ini. Selain itu, cara dan teknik mengimplementasikan model pembelajaran PjBL berbasis STEM ini pun dilatihkan pada guru-guru IPA. Metode yang digunakan adalah pelatihan dan mini workshop. Pelatihan dilaksanakan di kegiatan awal sebagai pendahuluan yang dilanjutkan dengan kegiatan workshop penyusunan dan pengembangan perangkat pembelajaran abad 21 dengan PjBL berbasis STEM. Hasil atau capaian dari kegiatan ini disajikan secara deskriptif dengan menunjukkan bahwa kemampuan guru-guru IPA dalam menyusun perangkat pembelajaran berupa RPP dan LKPD adalah sebagai berikut: 1) format perangkat pembelajaran 90\%. 2) kesesuaian KD dan Model PjBL 50\%, 3) ketepatan sintaks PjBL $70 \%$, dan 4) kesesuaian dengan LKPD $60 \%$.
\end{abstract}

Kata kunci: perangkat pembelajaran, project based learning, STEM, RPP, LKPD.

\begin{abstract}
This training has aims to train science teachers who are member of MGMP Science in West Region from Tasikmalaya Regency about how to make learning material (lesson plan and student worksheet) using STEM-based Project Based Learning model (PjBL). The problem commonly found by science teacher in class is that teachers are always use discovery learning model. The fact is some basic competencies require to implement learning models such as STEM-based PjBL to implemented in the classroom so science teachers needs to do refresher activity by following this training. In addition, the ways and techniques to implement STEM-based PjBL model are also given and trained to science teachers. The methods used is training and mini workshop. The initial activity was an introduction followed by a workshop to developing a $21^{\text {st }}$ century learning material with STEM-based $P j B L$ The results of this activity are presented descriptively by showing the ability of science teacher in developing learning material in the form of lesson plan and student worksheet are as follows: 1) 90\% learning material format, 2) the conformity of basic competency and 50\% PjBL model, 3) 70\% the accuracy of PjBL syntax, and 4) 60\% conformity with students worksheet.
\end{abstract}

keywords: learning material, project based learning, STEM, lesson plan, student worksheet. 


\section{PENDAHULUAN}

Seorang guru perlu memiliki keterampilan dalam menyusun perangkat pembelajaran sebagai bentuk strategi dalam pelaksanaan pembelajaran yang akan dilakukan. Perangkat pembelajaran tersebut terdiri dari Rencana Pelaksanaan Pembelajaran yang di dalamnya memuat skenario pembelajaran, soal evaluasi, dan Lembar Kerja Peserta Didik. Dalam penyusunannya perlu ada konsistensi dan kesinambungan antara kegiatan pembelajaran pada rencana pelaksanaan pembelajaran dan kegiatan peserta didik pada lembar kerja peserta didik serta model yang sedang diterapkan dalam pembelajarannya (Diella \& Ardiansyah, 2019). Umumnya guru memodifikasi rencana pelaksanaan pembelajaran yang sudah ada di berbagai sumber seperti internet ataupun dari rekan kerja yang lain, dan mencocokkan materi yang akan di pelajari dengan materi pada buku paket pegangan guru yang kemudian dilanjut dengan menggunakan lembar kerja peserta didik dari penerbit lain (Rukiati \& Susanti, 2016). Hal ini tentu akan menyebabkan apa yang diharapkan pada Kompetensi Dasar dan apa yang dilakukan peserta didik melalui sintaks model pembelajarannya tidak akan ada keterkaitan satu sama lain. Hal ini tentu akan mengakibatkan pembelajaran berlangsung tanpa makna dan urgensi penting.

Berdasarkan permendikbud tahun 2016, pendekatan pembelajaran yang digunakan pada mata pelajaran IPA di SMP adalah pendekatan saintifik (terdiri dari $5 \mathrm{M}$ yang meliputi mengamati, menanya, mengumpulkan data, mengasosiasi data dan mengomunikasikan). Namun, saat ini pembelajaran sains perlu ditambah pendekatannya yaitu dengan disesuikan pada tuntutan keterampilan Abad 21 di mana peserta didik diharuskan memiliki keterampilan 4C, yaitu Critical thinking, Creativity and Inovation, Collaboration, dan Communication (Trilling \& Fadel, 2009). Adanya penyesuaian ini tentu akan mempengaruhi format perangkat pembelajaran dan tuntutan model pembelajaran serta pendekatan pembelajarannya sehingga guru diharuskan memiliki keterampilan dalam penyusunan perangkat pembelajaran yang mampu menyesuaikan dengan keterampilan abad 21 tersebut.

Guru yang mampu menyusun sendiri perangkat pembelajaran dapat membuat guru tersebut mampu merencanakan dan melaksanakan proses pembelajaran yang sangat efektif dan sesuai dengan tuntutan Kompetensi Dasar, keterampilan abad 21 dan model pembelajaran (Meylani, Putra, \& Ardiansyah, 2018). Dalam hal ini, guru juga perlu memiliki keterampilan dalam menentukan model pembelajaran dan pendekatan pembelajaran yang dirasa layak untuk mampu menunjang keterampilan abad 21.

Beberapa masalah umum yang dilakukan oleh guru dalam menerapkan model pembelajaran di dalam kelas adalah guru hanya terbiasa menerapkan model Discovery Learning, tidak memahami esensi dari setiap sintaks model pembelajaran lain, dan menganggap bahwa lembar kerja peserta didik terlepas dari model pembelajaran yang diterapkan.

Model pembelajaran yang tepat diterapkan dalam proses pembelajaran di abad 21 salah satunya adalah Project Based Learning (PjBL) berbasis STEM (Science Technlogy Engineering dan Mathematic). Model Project Based Learning memiliki sintaks yang dapat menunjang keterampilan abad 21, yaitu penentuan pertanyaan mendasar, mendesain perencanaan proyek, menyusun timeline, monitoring, menguji hasil dan evaluasi pengalaman (Alec Patton, 2013). Project Based Learning berbasis STEM ini adalah model Project Based Learning yang diintegrasikan dengan STEM dan terdiri dari 5 proses, yaitu : reflection, research, discovery, application dan communication (Laboy-Rush, 2011).

Berdasarkan hasil observasi awal ditemukan permasalahan mitra, yaitu : (1) Guru masih belum memahami cara implementasi model pembelajaran Project Based Learning berbasis STEM, (2) guru belum memiliki informasi tentang format perangkat pembelajaran abad 21, (3) guru tidak memiliki keterampilan dalam menentukan model pembelajaran berdasarkan kurikulum, dan (4) guru tidak terampil dalam menyusun lembar kerja peserta didik berbasis model pembelajaran Project Based Learning. Padahal pada proses pembelajaran abad 21, keterampilan tersebut sudah harus dimiliki oleh seorang guru.

Berdasarkan dari permasalahan tersebut, maka tim pengusul bersama mitra mengadakan pelatihan Pengembangan Perangkat Pembelajaran Abad 21 dengan Model Pembelajaran Project Based Leaning Berbasis STEM bagi Guru IPA sebagai upaya peningkatan kompetensi guru dalam 
pelaksanaan proses pembelajaran IPA di kelas.

\section{METODE KEGIATAN}

Peserta dalam kegiatan pelatihan Pengembangan Perangkat Pembelajaran Abad 21 dengan Model Pembelajaran Project Based Learning berbasis STEM ini adalah seluruh guru IPA yang merupakan anggota MGMP (Musyawarah Guru Mata Pelajaran) IPA Wilayah Barat, Kabupaten Tasikmalaya. Pelatihan dilaksanakan selama empat hari di mitra pertama yaitu di SMPN 1 Singaparna pada tanggal 27 Juli - 30 Juli 2019.

Kegiatan ini menggunakan metode pelatihan dan lokakarya (workshop). Pelatihan berupa pemberian materi awal yang meliputi materi terkait format perangkat pembelajaran abad 21 yang terdiri dari rencana pelaksanaan pembelajaran dan lembar kerja peserta didik, keterampilan 4C yang meliputi critical thinking, creativity, collaboration, dan communication, penerapan model pembelajaran Project Based Learning berbasis STEM, dan lembar kerja peserta didik dengan menggunakan sintaks Project Based Learning berbasis STEM. Kegiatan Pengabdian ini dilanjut dengan workshop penyusunan dan pengembangan perangkat pembelajaran abad 21 dengan model pembelajaran Project Based Learning berbasis STEM.

Kegiatan ini memiliki tahapan sebagai berikut: 1) Pemaparan materi umum oleh tim pengabdian dari jurusan Pendidikan biologi, Universitas Siliwangi, 2) Workshop penyusunan dan pengembangan perangkat pembelajaran abad 21 dengan model Project Based Learning Berbasis STEM, dan 3) Presentasi Produk yang dilakukan peserta kegiatan dan Pemberian Feedback dari tim pengabdian.

\section{HASIL \& PEMBAHASAN}

Pada kegiatan pelatihan
pengembangan perangkat pembelajaran abad 21 dengan model pembelajaran Project Based Learning berbasis STEM ini menggunakan pendekatan deduktif. Pendekatan deduktif ini adalah kegiatan pembelajaran yang diawali dengan kegiatan pemaparan teori terlebih dahulu oleh tim pengabdian yaitu tentang teknik penyusunan perangkat pembelajaran dan penyusunan lembar kerja peserta didik serta teori tentang model pembelajaran Project Based Learning berbasis STEM yang kemudian dilanjutkan dengan kegiatan workshop yang meliputi kegiatan praktik penyusunan dan pengembangan perangkat pembelajarannya, yaitu meliputi rencana pelaksanaan pembelajaran dan lembar kerja peserta didik dengan model pembelajaran Project Based Leanring berbasis STEM. Materi awal yang diberikan oleh tim pengabdian adalah terkait format perangkat pembelajaran abad 21, komponen 4C, dan model pembelajaran Project Based Learning berbasis STEM. Selama proses workshop, peserta yang merupakan guru IPA dibagi ke dalam beberapa kelompok (3-4 orang) dan masing - masing kelompok diberikan kurikulum dari permendikbud no 37 tahun 2018 untuk dipilih materinya dan dibuatkan ke dalam bentuk perangkat pembelajaran berupa rencana pelaksanaan pembelajaran dan lembar kerja peserta didik abad 21 dengan menggunakan model Project Based Learning berbasis STEM. Kegiatan pelatihan ini juga disertai proses monitoring yang dilakukan secara intensif oleh tim pengabdian kepada masing - masing kelompok. Pada akhir sesi kegiatan, peserta diharuskan untuk mempresentasikan produk hasil buatan kelompoknya kemudian diberikan feedback oleh kelompok yang lain dan juga oleh tim pengabdian.

Berdasarkan kegiatan pelatihan ini maka didapatkan data berupa hasil capaian kemampuan guru-guru IPA yang terlibat dalam kegiatan pelatihan ini yang dapat dilihat pada grafik 1 di bawah ini. Terdapat empat aspek penilaian yang dijadikan sebagai data utama dalam kegiatan pelatihan ini, yaitu penilaian terkait format perangkat pembelajaran meliputi keseluruhan komponen pada rencana pelaksanaan pembelajaran secara umum, kesesuaian Kompetensi Dasar dan Project Based Learning, ketepatan dalam menggunakan sintaks Project Based Learning dan kesesuaian lembar kerja peserta didik dengan sintaks Project Based Learning.

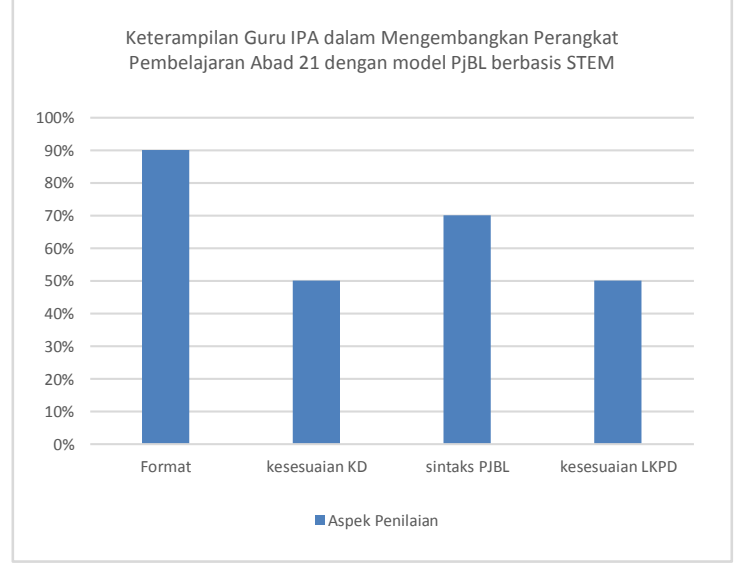


Grafik 1. persentase keterampilan guru IPA dalam mengembangkan perangkat pembelajaran abad 21 dengan menggunakan model Project Based Learning berbasis STEM

Data pada grafik tersebut menunjukkan bahwa keterampilan guru - guru IPA dalam menyusun dan mengembangkan perangkat pembelajaran memiliki capaian sebesar $90 \%$, diikuti oleh capaian keterampilan guru dalam menyusun kegiatan sesuai dengan sintaks Project Based Learning sebesar 50\%, keterampilan menyesuaikan materi pada Kompetensi Dasar dengan model Project Based Learning sebesar 70\%, dan keterampilan dalam menyusun lembar kerja peserta didik sebesar $60 \%$. Berdasarkan data tersebut guru memiliki keterampilan sangat baik $(90 \%)$ dalam menyusun perangkat pembelajaran abad 21 karena format perangkat pembelajaran tersebut sudah disediakan oleh tim pengabdian secara utuh untuk memudahkan dalam kegiatan workshop sehingga peserta tidak mengalami kesulitan yang berarti dalam aspek ini. Kemampuan guru dalam menyusun perangkat pembelajaran akan dimudahkan jika diberikan contoh yang riil dan didemonstrasikan secara langsung (Suharto, 2017).

Pada aspek keterampilan menyusun kegiatan pembelajaran dengan sintaks Project Based Learning memiliki capaian kategori baik (70\%). Aspek ini menuntut keterampilan guru IPA dalam menyesuaikan kegiatan peserta didik dalam proses pembelajaran di dalam rencana pelaksanaan pembelajaran dengan sintaks atau tahapan model Project Based Learning mulai dari sintaks giving essential question sampai sintaks mengevaluasi hasil karya. Capaian guru IPA pada kategori baik ini dikarenakan sintaks Project Based Learning dapat dengan mudah ditemukan di berbagai sumber dan referensi, salah satunya dengan menggunakan mesin pencari google. Namun, peserta tetap mengalami kendala dalam memahami sintaks Project Based Learning yaitu terutama pada sintaks giving essential question di mana tidak ada satu pun guru IPA yang memahami bahwa produk yang harus dibuat oleh peserta didik di dalam proses pembelajaran dengan menggunakan model Project Based Learning haruslah mampu menjawab pertanyaan esensial (masalah) yang guru berikan pada kegiatan inti awal. Kebiasaan yang dialami peserta di dalam kelas yang menerapkan model Project Based Learning adalah guru selalu memberikan instruksi langsung pada peserta didik untuk membuat suatu produk tanpa memberikan suatu masalah atau pertanyaan esensial apa yang harus dipecahkan dengan produk tersebut, hal ini mengakibatkan peserta didik kesulitan menemukan urgensi atau kebermanfaatan makna suatu produk yang mereka buat selama proses pembelajaran dengan menggunakan model Project Based Learning (Nuryadi \& Rahmawati, 2018). Dalam hal ini guru IPA masih berasumsi bahwa pembelajaran yang menghasilkan produk sudah pasti masuk ke dalam pembelajaran dengan model Project Based Learning, namun kenyataannya tidak seperti itu.

Dalam Aspek memilih materi yang sesuai dengan Project Based Learning, guru IPA memiliki capaian yang sedang $(50 \%)$ hal ini dikarenakan guru IPA masih menganggap bahwa semua materi IPA dapat menggunakan Project Based Learning selama di akhir pembelajaran peserta didik dapat menghasilkan suatu produk. Padahal guru perlu melihat Kompetensi Dasar pada kurikulum 2013 dan memperhatikan kata kunci pada Kompetensi Dasar seperti bila ada kata kerja operasional yang menuntut peserta didik untuk "membuat produk" maka guru harus menggunakan materi tersebut dan menerapkannya dengan menggunakan model Project Based Learning dalam proses pembelajarannya. Namun, saat kata kunci di dalam Kompetensi Dasar menuntut peserta didik "merumuskan gagasan" atau "menganalisis hubungan" walaupun di dalam pembelajarannya memungkinkan untuk membuat produk tetap saja dalam hal ini materi IPA tersebut tidak tepat jika diterapkan pembelajaran Project Based Learning. Keterampilan guru IPA tersebut sangat penting dan diperlukan karena jika guru mampu memilih materi yang tepat maka akan mampu meningkatkan kreativitas peserta didik dalam proses pembuatan produk akhir dalam Project Based Learning (Ummah, Inam, \& Azmi, 2019).

Pada keterampilan menyusun lembar kerja peserta didik Project Based Learning berada pada kategori baik (50\%). Hal ini dikarenakan guru masih terbiasa menggunakan lembar kerja peserta didik dari penerbit sehingga guru menjadi tidak terbiasa dalam mengembangkan lembar kerja peserta didik yang sesuai dengan model pembelajaran tertentu. Guru masih beranggapan bahwa lembar kerja peserta didik harus terdiri dari alat dan bahan serta prosedur yang sudah 
disediakan sehingga peserta didik langsung melakukan kegiatan pengamatan sesuai dengan prosedur yang disediakan dan peserta didik langsung menjawab pertanyaan pada lembar kerja peserta didik. Kenyataannya lembar kerja peserta didik yang menggunakan model Project Based Learning memiliki karakteristik dan kekhasan dalam formatnya yang membedakannya dengan lembar kerja peserta didik yang menggunakan model lain. Dalam lembar kerja peserta didik dengan model Project Based Learning, prosedur dan alat bahan yang diperlukan dalam kegiatan membuat produk, ditentukan oleh hasil kolaborasi peserta didik di dalam kelompoknya yang akan dituangkan dalam bentuk timeline untuk menyelesaikan produk yang mampu menjawab pertanyaan esensial di awal (Sari, Prasetyo, \& Wibowo, 2017).

Manfaat kegiatan pelatihan ini berdampak bagi guru IPA yang merupakan peserta dari kegiatan ini adalah guru - guru IPA menjadi termotivasi untuk mengubah format perangkat pembelajaran lama menjadi format perangkat pembelajaran abad 21 karena dirasa lebih detail dan mampu memunculkan keterampilan lain seperti keterampilan 4C (critical thinking, creativity, collaboration, dan communication). Selain itu, guru ingin terus mencoba menerapkan pembelajaran Project Based Learning dengan cara yang tepat sesuai sintaks dan sesuai dengan karakteristik materi yang disesuaikan dengan tuntutan Kompetensi Dasar pada kurikulum pada semester berikutnya.

Tim berasumsi bahwa motivasi guru IPA tersebut muncul akibat dari pemberian feedback yang dilakukan secara langsung saat kegiatan workshop dan feedback yang diberikan langsung dari rekan sesama peserta pelatihan (peer feedback). Menurut Alexander, Schunk, Greene, Winne, \& Winne (2019) bahwa pemberian feedback yang diberikan secara langsung baik oleh peer (rekan sebaya) atau instruktur secara langsung dapat memunculkan motivasi selama kegiatan berlangsung. Selain itu, perlu adanya pengawasan dari pihak sekolah atau supervisi untuk melakukan monitoring berkala terkait upaya guru IPA dalam menerapkan perangkat pembelajaran abad 21 dengan model pembelajaran Project Based Learning berbasis STEM di kelasnya. Upaya pengawasan oleh supervisi tersebut jika dilakukan secara berkala dapat meningkatkan kinerja guru IPA dalam perbaikan kualitas pembelajaran pada pertemuan selanjutnya (Harjum, 2018).
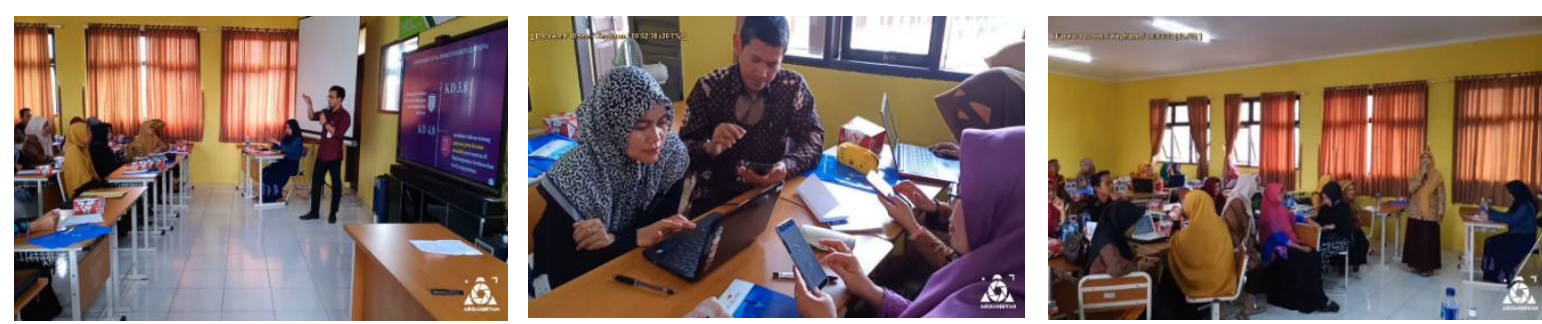

Gambar 1. Kegiatan Workshop (pemberian materi, proses kolaborasi workshop, dan presentasi hasil.

\section{KESIMPULAN \& SARAN}

Kegiatan pengabdian

yang diselenggarakan oleh tim pengabdian dari jurusan Pendidikan biologi, Universitas Siliwangi dengan tema Pengembangan Perangkat Pembelajaran Abad 21 dengan Model Pembelajaran Project Based Learning Berbasis STEM ini dapat memberikan manfaat dan pengalaman bagi guru IPA terutama dalam menyusun dan mengembangkan perangkat pembelajaran abad 21 yang meliputi rencana pelaksanaan pembelajaran dan lembar kegiatan peserta didik. Hasil workshop memperlihatkan bahwa guru IPA sudah sangat baik dalam menyusun perangkat pembelajaran abad 21 yang sesuai dengan format yang telah disediakan. Namun, kemampuan guru IPA dalam mengembangkan perangkat pembelajaran tersebut ke dalam model pembelajaran Project Based Learning berbasis STEM tidak sebaik ketika menyusun format rencana pelaksanaan pembelajaran saja. Kesulitan yang dialami oleh peserta adalah ketika menyesuaikan model Project Based Learning dan KD, ketepatan dalam menentukan sintaks Project Based Learning dan ketepatan dalam menyusun lembar kerja peserta didik.

Kegiatan pelatihan pengembangan perangkat pembelajaran abad 21 dengan model pembelajaran Project Based Learning berbasis STEM sebaiknya dilakukan secara berkala dengan meningkatkan kegiatan monitoring dengan tujuan untuk memperbaharui pengetahuan guru IPA yang tentu harus disesuaikan dengan tuntutan - tuntutan 
keterampilan yang pasti akan terus bertambah di masa yang akan datang. Pelatihan pengembangan perangkat pembelajaran abad 21 ini dapat dilakukan dengan mengintegrasikannya pada model pembelajaran yang lain seperti discovery learning, inquiry, dan problem based learning serta ditambah dengan keterampilan penyusunan perangkat penilaiannya.

\section{DAFTAR PUSTAKA}

Alec Patton. (2013). Work That Matters: The Teacher's Guide to Project-Based Learning. In Radiology management (1st ed., Vol. 35). https://doi.org/10.1097/ede.00000000000 00240

Alexander, P. A., Schunk, D. H., Greene, J. A., Winne, P. H., \& Winne, P. H. (2019). Handbook of Self-Regulation of Learning and Performances (2nd ed.; A. Patricia, H. S. Dale, \& J. A. Greene, eds.). https://doi.org/10.4324/9781315697048.c h3

Diella, D., \& Ardiansyah, R. (2019). Pelatihan Pengembangan LKPD berbasis Keterampilan Proses Sains Dan Instrumen Asesmen KPS Bagi Guru IPA. Publikasi Pendidikan, 9(1), 7. https://doi.org/10.26858/publikan.v9i1.68 55

Harjum, A. H. (2018). Penerapan Teknik Supervisi Observasi Kelas Untuk Meningkatkan Kinerja Guru Dalam Pembelajaran di SD Negeri 94 Tiroang Kabupaten Pinrang Sulawesi Selatan. Publikasi Pendidikan, 8(3), 153. https://doi.org/10.26858/publikan.v8i3.58 15

Laboy-Rush, D. (2011). Integrated STEM Education through Project-Based Learning. In Learning.Com. Retrieved from

http://rondoutmar.sharpschool.com/UserF iles/Servers/Server_719363/File/12.

13/STEM/STEM-White-Paper 101207 final[1].pdf

Meylani, V., Putra, R. R., \& Ardiansyah, R. (2018). Pengembangan Lembar Kerja Peserta Didik (LKPD) dan Pengayaan Materi Biologi Dalam Mata Pelajaran IPA Sesuai Kurikulum Nasional Bagi Guru IPA di Lingkungan SMP / Sederajat Se-Kota Tasikmalaya. Jurnal Pengabdian Siliwangi, 4(1), 13-17.

Nuryadi, N., \& Rahmawati, P. (2018). Persepsi peserta didik tentang penerapan model pembelajaran berbasis proyek ditinjau dari kreativitas dan hasil belajar peserta didik. Jurnal Mercumatika: Jurnal Penelitian Matematika Dan Pendidikan Matematika, 3(1), 53-62. https://doi.org/10.26486/jm.v3i1.656

Rukiati, E., \& Susanti, N. (2016). Pengembangan Media Pembelajaran Bahasa Inggris Di Madrasah Aliyah Annuriyah Jember. J-DINAMIKA (Jurnal Pengabdian Masyarakat), 1(1), 29-38.

Sari, K. A., Prasetyo, Z. K., \& Wibowo, W. S. (2017). Development of Science Student Worksheet Based on Project Based Learning Model To Improve Collaboration and Communication Skills of Junior High School Student. Journal of Science Education Research, 1(1). https://doi.org/10.21831/jser.v1i1.16178

Suharto, S. (2017). Kemampuan Guru Dalam Engembangkan Perangkat Pembelajaran Ips Berbasis Karakter (Studi Pada Guru Smp Negeri 3 Geger Madiun). Gulawentah:Jurnal Studi Sosial, 2(2), 116. https://doi.org/10.25273/gulawentah.v2i2 .1898

Trilling, B., \& Fadel, C. (2009). 21st Century Skills : Learning for Life in Our Times In Jossey-Bass (1st ed.) https://doi.org/978-0-470-47538-6

Ummah, S. K., Inam, A., \& Azmi, R. D. (2019). Creating manipulatives: Improving students' creativity through project-based learning. Journal on Mathematics Education, 10(1), 93-102. https://doi.org/10.22342/jme.10.1.5093.9 3-102 